\begin{tabular}{|c|c|c|c|}
\hline \multirow{4}{*}{$\begin{array}{r}\text { Glasnik hemičara i } \\
\text { tehnologa } \\
\text { Bosne i Hercegovine }\end{array}$} & ulletin of the & and Technologists & 2019 \\
\hline & & 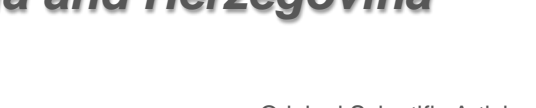 & 53 \\
\hline & Print ISSN: 0367-4444 & Original Scientific Article & \\
\hline & Online ISSN: 2232-7266 & UDC: $543.3: 641.562-053.31$ & $37-42$ \\
\hline
\end{tabular}

\title{
Determination of water content in infant formula
}

\author{
Jurković, J.*a, Sulejmanović, J. ${ }^{\text {b }}$ Tahmaz, J. a, Gavrić, T. ${ }^{\text {a }}$ \\ ${ }^{a}$ Faculty of Agriculture and Food Science, University of Sarajevo, Sarajevo, Bosnia and Herzegovina \\ ${ }^{b}$ Faculty of Science, University of Sarajevo, Sarajevo, Bosnia and Herzegovina
}

\begin{abstract}
Article info
Received: 24/04/2019

Accepted: 15/11/2019
\end{abstract}

Keywords:

water

infant formula

Karl Fischer

\begin{abstract}
Water is one of the most important constituents of food, very important to be accurately quantified. Furthermore, water content affects the stability and shelf life of food. The evaluation of most chemical parameters is based on dry mass and many methods use heating which result in losing all volatile compounds, including water. Also, it is much harder to extract all of water if we have a complex matrix.

Regarding this, the aim of this study was to determine water content in different infant formula by various methods. For examination of water content in three different types of infant formula three different techniques were used (oven sample processor, drying oven and halogen drying) and compared to classical Karl Fischer titration with two different solvents. Each sample was measured in ten probes, and classical Karl Fischer titration was used as a reference. The results showed that the reference method was the best regarding speed of measurement, amount of sample needed and obtained water contents (3.014.35\%), followed by Karl Fischer in boiling methanol (2.80-4.30), oven sample processor (2.96-4.23\%), halogen drying (2.74-4.03\%) and drying oven (2.38-3.52). Methods using heating could not remove all water from the sample within a reasonable time.
\end{abstract}

*Corresponding author:

Jurković Josip

E-mail: josssjurkovic@yahoo.com

Phone: +38763876 658

\section{INTRODUCTION}

The amount of water in food samples is one of the most commonly measured parameters, since it is a criterion of nutritive value, taste, shelf time, etc. (Isengard, 2001). Water is present in several different forms in almost all food. For instance, in dried products a small amount of water is present, while in beverages a very high amount of water is contained (Jurković, 2018). Determination the water content in food is not an easy task, especially if the sample has a complex matrix like infant formula. The results obtained should represent only the content of water without the content of volatile compounds, which is often not the case. On the other hand, it is difficult to evaporate all the water in complex samples. Thus, water quantification is a challenge for practical reasons. Furthermore, because of so many different methods for water content determination, it is a question which one gives the correct value (Isengard, 2001).

There are few main problems when we want to determine water content in food: loss of volatile compounds - by heating the sample (mass loss techniques); sample contamination; Maillard reaction, etc. (Jurković, 2018).

Additionally, since water could remain trapped in a complex sample, sometimes it is hard to evaporate all of the water in a reasonable period of time. Therefore, extraction water with a suitable solvent is a better way than heating it.

One of the most complex samples for determination water content is infant formula, which is a synthetic version of mother`s milk, known as a dietary substitute. The infant formula contains all compounds that are important for baby`s growth and development: including blending fats, proteins, minerals and carbohydrates (Kotb, Farahat, ElDaree, 2016). It is commonly produced on an industrial scale from cow milk (formulation of cow milk proteins). On the other hand, the powder form is obtained by a spray drying process, which can ensure a pretty low moisture content. Depending on the children age, the formulas are divided into two basic types: a) products for newborns, b) products for children older than 4 or 6 
months (Molska, Gutowska, Baranowska-Bosiacka et al., 2014).

According to Codex Alimentarius, infant formula is defined as a breast-milk substitute specially manufactured to satisfy the nutritional requirements of infants during the first months of life up to the introduction of appropriate complementary feeding. An infant is a person not older than 12 months of age. Industrial product infant formula has to meet some requirements, even it is processed by physical means it has to be adequate packaged to prevent spoilage and contamination under normal conditions of handling, storage and distribution in the country where the product is sold (Codex Alimentarius Commission, 2015). Furthermore, according to Codex Alimentarius, the moisture content of infant food has to be governed by good manufacturing practice for the individual product categories and should be at a level that provides minimum loss of nutritive value and within a level that microorganisms cannot reproduce (Codex Alimentarius Commission, 2017). For powdered milk products, moisture below $5 \%$ is recommended. Many non-European countries have standards for maximum moisture level in powdered infant food.

For instance, the allowed maximum level of moisture in India is $\leq 4.5 \%$ (FSSAI 2017), in China $\leq 5 \%$ (GB 10765 2011) and in east African countries $\leq 3 \%$ (EAS 78, 2006). Several studies have reported low moisture content in different infant food: $1.96 \%$ (Gasmalla Khadir, Musa et al. 2013), 0.42-2.55 (Kotb, Farahat, El-Daree et al. 2016) and 1.97-2.02\% (Tham, Wang, Yeoh et al. 2016) and less than 2.5\% (Semeniuc, Muste, Rotar et al. 2012). On the other hand, there is no literature data related to accurate water content analysis in infant food, which is the aim of this study.

\section{EXPERIMENTAL}

\section{Material and methods}

In this study we used different kinds of milk based infant formula, for different stages of baby`s development:

1) Infant formula 1 - for period after birth until six months of age

2) Infant formula 2 - for period between six and 12 months of age

3) Infant formula 3 - for babies older than twelve months

All tested kinds of infant formula had different amounts of proteins, sugars, fats and other constituents.

Oven drying; halogen drying, combined Karl Fischer titration with heating oven (oven sample processor) and Karl Fischer titration with boiling water were used for determination of water content and compared to classical Karl Fischer titration, which was used as a reference.

\section{Karl Fischer titration - reference}

This is a direct method based on a chemical reaction that is quantitative and selective for water determination (Isengard, King, Reh, 2006; Isengard, Präger, 2003). Measurements of water content were carried out on Titrando 890 Metrohm (Metrohm, Herisau, Schwitzerland) equipped with a volumetric Karl Fischer titration cell and thermostat, using Solution 1- which is a mixture of hydranal (Riedel de Haën) and formamide (Riedel de Haën), as a solvent - reference.

The second solvent used was boiling methanol (Riedel de Haën) - not a reference.

\section{Application and optimisation of applied methods}

\section{Karl Fischer titration}

The extraction of water from the sample requires the selection of the right solvent (Isengard, 2008). After several solvents used for testing (Schöffski, 2001), a mixture of hydranal and formamide was selected for the first titration and only boiling methanol for the second. Boiling methanol vapour can absorb water from all parts of the titration cell back to titration. In addition, the extraction time should be enough to ensure the quantitative extraction of water from the sample. Prior to the Karl Fischer titration, instrument calibration was performed using a standard with a known amount of water $(10.00 \%)$. Liquid standards were introduced into the sample cell with a $10 \mathrm{~cm}$ syringe needle, while the sample (0.02 to $0.03 \mathrm{~g})$ was introduced by spoon specialized for Karl Fischer titrators. The syringe mass was measured before and after the addition of the sample to the titration cell, followed by $20 \mathrm{~s}$ of mixing. The additions of titrant were larger at the beginning, while close to the endpoint (potentiometrically determined) the additions were smaller $(0.001 \mathrm{~mL})$. For infant formula samples titrations, the duration was around $450 \mathrm{~s}$ (7.5 min), until all water was extracted. Each sample was measured in ten probes.

\section{Oven drying}

Mass loss measurements (subtraction of sample mass measured before and after heating) were performed at $105^{\circ} \mathrm{C}$ using a laboratory oven, Binder FDL 115 (Binder, Mount Holly, USA). The main problems during heating could occur because of volatilization of compounds which gain higher results or the insufficient evaporation of water.

Classical Oven is an old and very well-defined method, easy to use for determination of mass loss, but time consuming. For better distribution of sample, pre-dried silicate sand was used. Lactose standard (with 5.05\% of water, Fluka) was used for determination of water content.

The analyzed samples (2.000-4.000g) weighted into glass weighting bottles were mixed with pre-dried sand and dried at $105^{\circ} \mathrm{C}$, until a constant mass was obtained.

\section{Halogen drying}

In order to rapidly determine the moisture content, a thermo gravimetrically halogen drying method could be used (Morales, Van Boekel, 1998). These measurements were made using a Sartorius MA 40 (Sartorius, Göttingen, Germany). The drying process is highly dependent on the radiation temperature and the distribution of the sample in the sample holder. The distribution of the sample on the sample plate should be even in all parts of the plate. In the case that samples would not be distributed in the layers of similar thickness, it is hard to evaporate the water from the thicker parts. 
Therefore, halogen drying was carried out at $100^{\circ} \mathrm{C}$ within 60-70 min and sample was inserted in the sample holder with a plastic spoon (1.000-2.000g).

\section{Combined Karl Fischer titration}

Vaporization of water from a sample and Karl Fischer titration are combined within this direct method (Felgner, Schlink, Kirschenbühler et al., 2008; Kestens, Connely, Bernreuther, 2008). A sample is heated in the oven (774 Oven Sample Processor, Metrohm, Herisau Schwitzerland) and the formed water vapor is introduced into the coulometric Karl Fischer Cell by dried air as a gas carrier. Dry air is achieved by passing of air trough molecular sieves. Water that comes out of the sample is due to heating. However, some water can remain. Inside of this cell titrant is formed by electricity.

The main parameter which should be optimized is a temperature for water vaporisation. The temperature of measurement depends on the composition of the sample. Thus, the adequate temperature $\left(120^{\circ} \mathrm{C}\right)$ was chosen by "temperature ramping" $\left(1^{\circ} \mathrm{C} / \mathrm{min}\right)$ from 20 to $250^{\circ} \mathrm{C}$. Additionally, it was necessary to find the best flow rate of a gas carrier. Prior to sample analysis, water content was measured in blanks and standards. Lactose with known amount of water (5.05\%) was used as standard, while blank was only vial with air. Other experimental conditions were previously reported in detail by Jurković (2018): measurement duration (65-100 min); stop criteria (absolute drift of $20 \mu \mathrm{g} / \mathrm{min}$ ); sample mass (0.1500$0.2500 \mathrm{~g}$ ) was introduced into the vial with a plastic spoon and the vial was closed. Since this method measures water in the air formed by heating the sample, content of water was measured in the closed vial.

Five blank probes were first measured, followed by ten probes of sample measurements. Results of the blank probe were subtracted from the result of sample measurement.

\section{RESULTS AND DISCUSSION}

Several different techniques were used to determine the moisture (water) content in infant formula samples, i.e. classic Karl Fischer titration with different solvents, combined Karl Fischer titration, oven drying and halogen drying. The results are shown in Figures 1, 2 and 3. All of these methods are used for moisture content, except Karl Fischer titration which represents the water content determination in food samples. The results obtained showed, as expected, that for all infant formulas analysed, the highest results were obtained when water content was determined or when Karl Fischer titrations were applied. However, analysing the results in more detail, it could be concluded that the moisture content determined by halogen drying is the closest to the Karl Fisher titration results, but is highly dependent on the radiation temperature as well as the expertise of analysts. Furthermore, analysing the results obtained by conventional oven drying, it could be concluded that the results were lower and that the $0.83 \%$ of difference in results represents only $81 \%$ of the result obtained by the reference method (classical Karl Fischer), which is a significant difference. Even more, other differences between methods were also shown in Table 1 , and are related to time of measurement, mass of the sample and standard deviation. In that meaning, the best method recommended for water determination is Karl Fischer titration (classical and in boiling methanol), while the classical oven drying method is more suitable for labeling only the moisture content in different food samples.

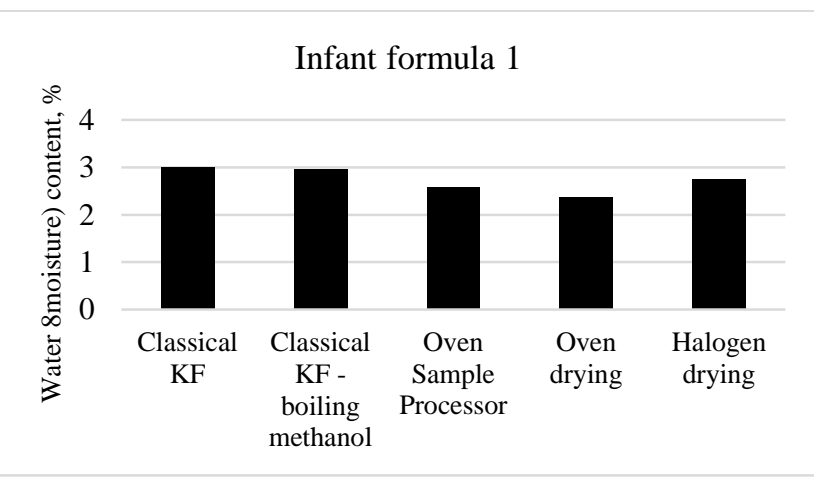

Figure 1. Water content in Infant formula 1.

Infant formula 2

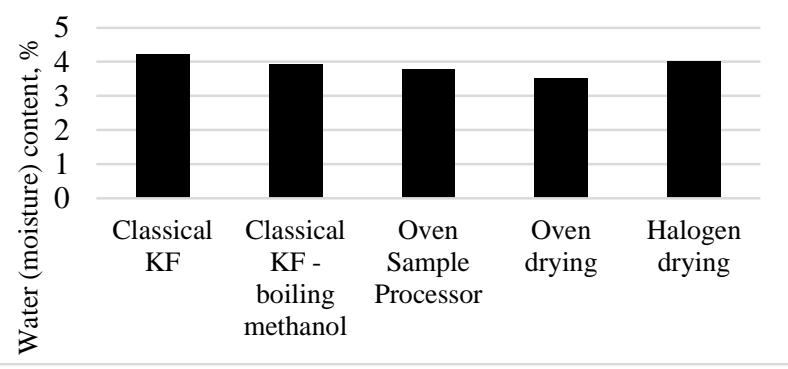

Figure 2. Water content in Infant formula 2.

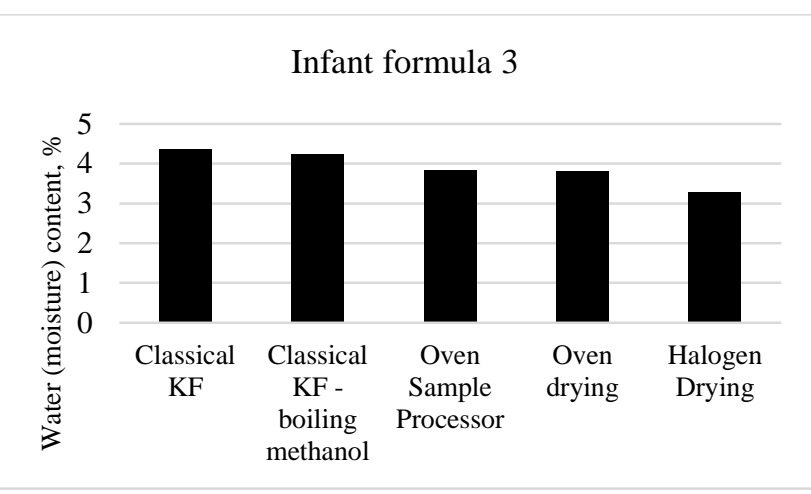

Figure 3. Water content in Infant formula 3.

The results of the water content for each sample together with main parameters of the analytical methods and the main statistical data are shown in Table 1 . The results obtained by all the methods used were approved by Codex Alimentarius Commission (2015), which states that the water content of the infant formula should be below 5\% and compared to the national standard in India and China where the water content should be $\leq 4.5$ and $\leq 5 \%$ (FSSAI 2017; GB 10765 2011), respectively. Results of water content ranged between 2.38 and $4.35 \%$ (Table 1) and depended on the sample type and the method of water determination applied. 
Table 1: Comparison of results of water content for each sample with different analytical methods

\begin{tabular}{|c|c|c|c|c|c|}
\hline \multicolumn{6}{|c|}{ Infant formula 1} \\
\hline & Classical KF & KF - boiling methanol & OSP & Oven drying & Halogen drying \\
\hline Time & $400 \mathrm{~s}$ & $700 \mathrm{~s}$ & $65-100 \mathrm{~min}$ & $6 \mathrm{~h}$ & $60-70 \mathrm{~min}$ \\
\hline Mass & $0.02-0.03 g$ & $0.02-0.03 g$ & $0.01-0.02 \mathrm{~g}$ & $2-3 g$ & $1-2 \mathrm{~g}$ \\
\hline Maximum & 3.10 & 3.16 & 2.63 & 2.48 & 2.87 \\
\hline Minimum & 2.95 & 2.80 & 2.56 & 2.28 & 2.66 \\
\hline Median & 3.01 & 2.97 & 2.59 & 2.35 & 2.74 \\
\hline Average & 3.00 & 2.96 & 2.59 & 2.38 & 2.74 \\
\hline STDEV & 0.04 & 0.12 & 0.02 & 0.09 & 0.08 \\
\hline \multicolumn{6}{|c|}{ Infant formula 2} \\
\hline & Classical KF & KF in boiling methanol & OSP & Oven drying & Halogen drying \\
\hline Time & $450 \mathrm{~s}$ & $650 \mathrm{~s}$ & $65-100 \mathrm{~min}$ & $6 \mathrm{~h}$ & 60-70 min \\
\hline Mass & $0.02-0.03 g$ & $0.02-0.03 g$ & $0.01-0.02 \mathrm{~g}$ & $2-3 g$ & $1-2 \mathrm{~g}$ \\
\hline Maximum & 4.29 & 4.07 & 3.81 & 3.59 & 4.16 \\
\hline Minimum & 4.18 & 3.81 & 3.74 & 3.38 & 3.95 \\
\hline Median & 4.23 & 3.92 & 3.78 & 3.57 & 4.01 \\
\hline Average & 4.24 & 3.93 & 3.78 & 3.52 & 4.03 \\
\hline STDEV & 0.08 & 0.07 & 0.03 & 0.09 & 0.08 \\
\hline \multicolumn{6}{|c|}{ Infant formula 3} \\
\hline & Classical KF & KF in boiling methanol & OSP & Oven drying & Halogen drying \\
\hline Time & $450 \mathrm{~s}$ & $700 \mathrm{~s}$ & 65-100 min & $6 \mathrm{~h}$ & $60-70 \min$ \\
\hline Mass & $0.02-0.03 g$ & $0.02-0.03 \mathrm{~g}$ & $0.01-0.02 \mathrm{~g}$ & $2-3 g$ & $1-2 \mathrm{~g}$ \\
\hline Maximum & 4.45 & 4.30 & 3.87 & 3.34 & 3.93 \\
\hline Minimum & 4.26 & 4.13 & 3.78 & 3.23 & 3.62 \\
\hline Median & 4.36 & 4.23 & 3.83 & 3.27 & 3.86 \\
\hline Average & 4.35 & 4.23 & 3.83 & 3.28 & 3.79 \\
\hline STDEV & 0.05 & 0.06 & 0.03 & 0.05 & 0.13 \\
\hline
\end{tabular}

The results obtained were much higher in comparison to the results of the water content reported in the literature, i.e., for powdered infant formulas reported by other authors, the water content varied between 0.42 and $2.55 \%$ (Kotb, Farahat, El-Daree, 2016; Tham, Wang, Yeoh et al. 2016; Gassmalla, Khadir, Musa et al. 2013; Semeniuc, Muste, Rotar et al. 2012), depending on country of origin, product type (cereal or milk based) and producer. As mentioned above, certain differences in the methods used are mainly related to the amount of water (moisture), speed of measurement and precision. Regarding the time, the fastest method was Karl Fischer titration method (measurements were up to 8 minutes), while the longest method was the Oven drying (6-8 hours). Additionally, the Classical Karl Fischer method could be approved and be even shorter, with applying higher temperature of analysis, since the extraction of water from the samples depends on temperature.

Furthermore, Karl Fischer in boiling methanol showed lower results for water content comparing to the reference method (classical Karl Fisher method) which implies that methanol is not a better solvent than Hydranal (used in classical Karl Fischer titration) for extraction of water from infant formula samples. Additionally, for the combined Karl Fisher titration method and the heating method (Oven sample processor) the main disadvantage is the time of measurement and other parameters that should be controlled what makes the method complicated. Also, it is not possible to have absolutely dried air as a carrier. Although the determination of water seems to be one of the simplest parameters that can be determined, the difficulties mentioned above by applying different methods as well as the analysis of a complex matrix, i.e. infant formula, requires more attention and expertise from analysts to distinguish which kind of method is approriate for water and moisture determination.

\section{Precision of methods}

Under the described conditions, ten portions of each sample (Infant formula 1, 2 and 3) were analysed for the determination of water content by various methods. The lowest STDEV of all analysed samples was obtained from the results of the method of Oven sample processor (0.02), followed by the Classical Karl Fischer titration method (0.04). The standard deviations obtained indicate that both methods have very good repeatability and precision.

Furthermore, a comparison of obtained results of four tested methods (KF with boiling methanol, Oven sample processor, Oven Drying and Halogen Drying) with the Classical Karl Fischer titration method for water determination was performed by t-test analysis at $95 \%$ confidence level. These values revealed that there was no good agreement for the water determination between the four methods and the Classical Karl Fischer method as the reference method. Additionally, there was a significant difference between the results by performing ttest at 95\% confidence level. Unfortunately, regarding obtained results, it can be concluded that with these four tested methods, all the water from samples could not be removed. 


\section{CONCLUSION}

Lower results of water content are achieved after application of methods based on sample heating, because it is hard to evaporate all the water in a reasonable period of time. Also, the formation of crust on the surface od the sample blocks water from evaporating. Due to the complex matrix of infant formula, the reference method (KF) showed the best results.

\section{REFERENCES}

Bünung - Pfaue H. (2003). Analysis of water in food by near infrared spectroscopy, Food Chemistry, 82, 107115.

Codex Alimentarius Commission (1999). Codex Stan 207- 1999: Codex standard for milk powders and cream powder (revised 2014). Retrieved 10 March 2015 from http://www.codexalimentarius.org/download/standard s/333/ CXS_207e.pdf.

Codex Alimentarius Commission (2015). Codex Stan 72 1981 Amendment: 1983, 1985, 1987, 2011 and 2015. Standard for infant formula and formulas for special medical purposes intended for infants, FAO and WHO

Codex Alimentarius Commission. (2017). Codex Stan 74 1981 Amendment: 2006, revised 2017. Standard for processed cereal based foods for infants and young children, FAO and WHO.

EAS 78 (2006). Milk based baby foods - Specification. East African Standards, East African Comunnity (https://law.resource.org/pub/eac/ibr/eas.78.2006.pdf)

GB 10765-2010 (2011). National Standard for food Safety, National Food Safety Standards Infant Formula. The Ministry of Health PCR China.

Felgner A., Schlink R., Kirschenbühler P., Faas B., Isengard H-D. (2008). Automated Karl Fischer titration for liquid samples-water determination in edible oils, Food Chemistry, 106, 1379-1384.

FSSAI (2017). F. No. Stds/03/Notification (IFR)/ Food Safety and Standards (Foods for Infant Nutrition) Regulations. Food Safety and Standard Authority of India (https://fssai.gov.in/dam/jcr:0c893922-b9614439-b1d0d8da47f7f36c/DraftWTOTBT

Notification_Food_Infant_Nutrition_27_12_2017.pdf)
Gasmalla M. A., Khadir. E. K., Musa A., Aboshora W., Zhao W. (2013). Evaluation of some physicochemical parameters of three commercial milk products. Pakistan Journal of Food Sciences, 23, 62-65.

Isengard H-D., King R., Reh C. T. (2006). Proposal of a new reference method to determine the water content of dried dairy products, Food Chemistry, 96, 418-422.

Isengard H-D., Präger H. (2003). Water determination in products with high sugar content by infrared drying, Food Chemistry, 82, 161-167.

Isengard H-D. (2008). Water determination-Scientific and economic dimensions, Food Chemistry, 106, 13931398.

Isengard H-D. (2001). Water content, one of the most important properties of food, Food Control, 12, 395400.

Jurković J. (2018). Water determination in samples with high sugar and protein content, Technologica Acta, 11, 45-50.

Kestens V., Connely P., Bernreuther A. (2008). Vaporisation coulometric Karl Fischer titration: A perfect tool for water content determination of difficult matrix reference materials, Food Chemistry, 106, 1454-1459.

Kotb M. A., Farahat M. F., El-Daree H. B. (2016). Chemical composition of infant milk formulas sold in Alexandria, Egypt. Canad J Clin Nutr, 4 (1), 4-17.

Molska A., Gutowska I., Baranowska-Bosiacka I., Noceń I., Chlubek D. (2014). The content of elements in infant formulas and drinks against mineral requirements of children, Biological trace element research, 158, 422-427.

Morales F. J., Van Boekel M. A. J. S. (1998). A study on Advanced Maillard Reaction in heated Casein/Sugar Solutions: Color formation. International Diary Journal, 8, 907-915.

Schöffski K. (2001). New Karl Fischer reagents for the water determination in Food, Food Control, 12, 427429.

Semeniuc A. C., Muste S., Rotar M. A., Suharoschi R., Tofană M. (2012). Influence of the storage conditions on physicochemical parameters of infant formula. Journal of Agroalimentary Processes and Technologies, 18 (1), 61-64.

Tham, T. W. Y., Wang, C., Yeoh, A. T. H., Zhou, W. (2016). Moisture sorption isotherm and caking properties of infant formulas. Journal Food Engineering, 175, 117-126. 


\section{Summary/Sažetak}

Voda je jedan od najvažnijih konstituenata hrane, stoga je vrlo bitno njeno precizno kvantificiranje. Nadalje, sadržaj vode utiče i na stabilnost i rok trajanja hrane. Kako se određivanje većine hemijskih parametara temelji na promjeni suhe mase, mnoge metode upravo koriste zagrijavanje koje rezultira gubitkom svih hlapivih spojeva, uključujući i vodu. Također, mnogo je teže izdvojiti svu vodu ako je uzorak složenog matriksa. S tim u vezi, cilj ovog rada bio je utvrditi sadržaj vode u različitim formulama za dojenčad različitim metodama. Za određivanje sadržaja vode u tri različite vrste formule za dojenčad, tri različite tehnike su korištene tehnike (kombinirana Karl-Fischer-ova titracija nakon sušenja uzorka u peći, klasično sušenje uzorka u peći i sušenje halogenom) te upoređene sa klasičnom Karl Fischer-ovom titracijom sa dva različita rastvarača. Svaki uzorak je mjeren u deset paralelki, a klasična Karl Fischer-ova titracija je korištena kao referentna metoda. Rezultati su pokazali da je klasična Karl Fischerova titracija (referentna) najbolja metoda u pogledu brzine mjerenja, količine potrebnog uzorka i dobivenog sadržaja vode (3.01-4.35\%), nakon čega slijedi Karl Fischer-ova metoda u ključalom metanolu (2.80-4.30), kombinirana Karl Fischer-ova metoda nakon sušenja uzorka u sušnici (2.964.23\%), metoda sušenja halogenom (2.74-4.03\%), te metoda klasičnog sušenja u sušnici (2.38-3.52). Dobiveni rezultati potvrđuju da metode koje koriste samo sušenje ne mogu ukloniti svu vodu iz uzorka u razumnom vremenskom periodu. 